\title{
The History of Mental Handicap in Bristol and Bath*
}

\author{
J. JANCAR, Honorary Consultant Psychiatrist, Stoke Park Hospital, Bristol
}

The cities of Bristol and Bath have played an eminent role in the history of mental handicap.

Unfortunately, documentation is rather scanty, particularly on the pre and post Reformation era but much more is known about the Holy Cross Hospital in Bath, perhaps the oldest mental handicap hospital in Great Britain. The Romans contributed to its foundations when they built Fossway Road on the outskirts of Bath which the pilgrims later used to visit Glastonbury.

Sited next to the Holy Cross Hospital is the Chapel of St Mary Magdalen, Holloway (Holy Way). The earliest edifice on this site would appear to have been erected before the Norman Conquest, as stated at the end of an old Saxon Manuscript of the Four Gospels in Latin dated 983. The Chapel was built beside a spring water well where the pilgrims used to stop to rest and pray. A hostel was built next to the Chapel in 1212 and in 1235 it was labelled as a lepers' house. In 1263 an undated deed appeared in the Bath Cartulary which records a grant of land by John Wyssey to the Hospital of St Mary Magdalen in Holeweia and to the brothers and sisters there serving God. At the dissolution of the monasteries in 1534, the Magdalen Chapel remained open and the Holy Cross Hospital continued with the reception of lunatics. ${ }^{1}$

In the present Verger's house, former hospital, is a tablet which reads in Latin:

'Anno salutis MDCCLXI haud multo post Inaugorationem Georgii Tertii Auspicatifsimi Regis: Hoc MOROTROPHIUM quod ante ducentos et septuaginta annos JOHANNES CANTLOW prior Bathoniensis fundavit Vetustate pene collapsum ieaedificavit DUEL TAYLOR Bathiniae Rector et hujus Hospitii Magister'.

The sense of this inscription was translated by the British Museum:

"In the year of Our Lord 1761, not long after the coronation of the most illustrious King George III, this lunatic asylum, founded two hundred and seventy years before by John Cantlow, Prior of Bath, and almost collapsed through age, was rebuilt by Duel Taylor, Rector of Bath, and master of this lodging", (1491 is therefore the year of the foundation of the hospital).

The word MOROTROPHIUM on the tablet is of great interest. MOROTROPHIUM consists of two Greek words, MOROs-stupid/feeble minded, moron-and TROPHEIA, place for nursing or caring, therefore the modern translation should read 'Mental Handicap Hospital'. This is confirmed by the last but one word on the tablet 'Hospitii' meaning home for the needy or afflicted.

-An abridged Presidential Address, Bristol Medico-Chirurgical Society, October 1985.
St Peter's Hospital in Bristol should be better known, having been probably the earliest asylum of any size in the country apart from Bethlem. In 1698 the first patients were received. The building had been in use as a private residence since 1402 while during most of the seventeenth century it was used partly as a residence and partly as a sugar refinery, and referred to as the 'Sugar House'.

From 1696 to 1698 it was in use as a mint, and continued to be popularly known as 'the Mint'. Patients were admitted under the Bristol Poor Act of 1696 which was an historic piece of local legislation, anticipating by 86 years one of the provisions of Gilbert's Act of 1782, whereby parishes were permitted to combine for the more efficient administration of the Poor Law. It was inspired and published by John Cary in 1695. The first inmates were 100 boys, but these were soon joined by other inhabitants, some aged, some infirm, some lunatic and some mentally handicapped. Thus the transformation of the workhouse into a hospital began almost at once. St Peter's Hospital continued to be used as a lunatic asylum until 1861 when its patients were transferred to a newly opened lunatic asylum at Fishponds. The destruction of St Peter's Hospital by enemy fire in 1940 was a tragic loss to the City of Bristol. Dr T. Dover was the first consultant physician at St Peter's Hospital. He is remembered for his 'Dover's powder' (pulvis ipecacuanhae et opii).

In 1735 the Bristol Royal Infirmary was instituted where pychiatric patients were seen in the out-patients' department by psychiatrists including Dr E. Long Fox and Dr J. C. Prichard who wrote one of the first textbooks on insanity. Very often mentally handicapped people were admitted to a lunatic asylum. In 1740, a private lunatic asylum was opened in Fishponds by Dr J. Mason who earlier managed his father's small mental establishment at Wickwar. About 1790, the pioneering treatment of the mentally ill by 'moral' treatment and group therapy was first introduced by Dr E. L. Fox in a small Quaker's asylum at Cleeve Hill, Downend, then in Brislington House (1804) and later Northwood Asylum in Winterbourne which was opened by Henry Fox in 1845 .

At the time of the cholera epidemic in Bristol in 1832, some patients were transferred from St Peter's Hospital to an old prison building at Stapleton, which was built in 1779 to house Spanish, Dutch and French naval prisoners of war. Most of the institution was rebuilt in 1861 and renamed Stapleton Institution for Mental Defectives in 1918. In 1948 it became Stapleton Hospital for Geriatric Illness and was renamed again in 1956 as Manor Park Hospital.

Cambridge House Flax Bourton was opened in 1842 as a Poor Law institution. In 1917, part of Cambridge House was used to house the mentally handicapped and later became known as Farleigh Hospital and in 1971 joined the 
United Bristol Hospitals with Yatton Hall which opened in 1919. Both hospitals are now providing the services for the Bristol and Weston Health Authority.

In 1846 two sisters by the name of White opened a small school for mentally handicapped children in Bath and this eventually developed into the Rockhall House School, opened in 1891 and amalgamated later with the Holy Cross Hospital.

Mary Carpenter, a Victorian reformer, opened Red Lodge Reformatory School in 1854 and the Kingswood Approved School in 1852 . She was a pioneer in the treatment of juvenile delinquency.

In 1890, Miss Harriett Wemyss opened St Mary's Home, Painswick, near Stroud, for mentally handicapped girls. This home is still housing mentally handicapped people from the Gloucester Health Authority. Three years later a similar home for mentally handicapped girls was opened in Bristol; the Chasefield Home, 188 Fishponds Road.

Towards the end of the last century and at the turn of this century there were four remarkable people who played a very important part in the development of the services for the care of the mentally handicapped people in Bristol, Bath and Somerset. A great pioneer in this field was Miss Norah Fry. The Norah Fry Hospital was named after her in her maiden name, and later when she married, the first Chair in Mental Health at Bristol University was also named after her; Mrs Norah Cook Hurle. Another influential man was the late Marquess of Bath and the two other people were the Reverend Burden and Mrs Burden.

The Burdens. The Reverend Harold Nelson Burden and Mrs Katherine Mary Burden came to Bristol in 1895, when Mr Burden was appointed chaplain to Horfield Prison. Their arrival in Bristol opened a new chapter in the history of the care and treatment of down and outs and especially of mentally handicapped people. Mr and Mrs Burden first came in contact with the people in real need and misery when they worked in the East End of London. They were also influenced by the work of Miss Octavia Hill (18421912), who was regarded as an authority on the lives of the poor in London and was a friend and disciple of Ruskin. $\mathrm{Mr}$ and Mrs Burden were instrumental in the promotion and erection of the Royal Victoria Home near Horfield Prison.

The passing of the Inebriates Act of 1898 made much larger accommodation necessary for inebriates. Premises were therefore taken at Brentry and the assistance of County and County Borough Councils was sought. Twenty-four of these decided to contribute to the establishment of the Brentry Certified Inebriate Reformatory. Two villages were erected-the upper for females and the lower for males. Brentry House was adapted for offices and a residence for a superintendent. For three years, both $\mathrm{Mr}$ and Mrs Burden gave it their continuous attention. Every woman who entered the institution came under Mrs Burden's influence and received her help. Mr Burden remained on the Brentry Certified Institution Board of Management as vicechairman until his death in 1930.

As the Inebriates Act proved to be ineffective and as the number of mentally handicapped patients was increasing, the Brentry Certified Inebriate Reformatory ceased to exist in January 1922 when it became Brentry Certified Institution within the meaning of the Mental Deficiency Acts, 1913 and 1919. The newly designated institution provided 220 beds for male mentally handicapped patients over the age of 18 years. The aim of the institution was to occupy the patients as much as possible.

In 1930 Brentry Certified Institution was renamed Brentry Colony and Dr R. G. Rudolf was appointed Medical Superintendent. He was a renowned researcher and produced a number of interesting publications. In 1948 Brentry Colony merged with Hortham Colony. ${ }^{2}$

$\mathrm{Mr}$ and Mrs Burden first bought Eastern Counties Institution, East Hearling, Norfolk in 1904 and then Sandwell Hall, Handsworth, Staffordshire in 1906. In 1909 they acquired from the Duke of Beaufort, the Dower House, Stoke Park, later known as Stoke Park Colony. Whittington Hall, Chesterfield was opened in 1912.

The Reverend Burden travelled through Europe trying to find the latest treatment for mental handicap and brought back the idea for heliotherapy, an open-air treatment practised on the Continent at that time, to increase vitality, weight and resistance to disease. He built five two bedded revolving houses among the trees near the hospital ward for convalescent patients and a sheltered enclosure between the wards used for sun baths. During the summer, large tents were provided as dormitories, dining rooms and play rooms. As the demands for more beds grew, Mr Burden purchased more property, and Heath House was acquired in 1911 and Stapleton Grove-Beech House (now Purdown Hospital) in 1916 followed by Hanham Hall and Leigh Court in 1917. Leigh Court was closed in 1985 but it is pleasing that it was bought by a voluntary organisation and again is providing accommodation for mentally handicapped people.

Mrs Burden died in 1919, and Mr Burden married Miss R. Williams, who was the Superintendent of Stoke Park.

Mr Burden was not content merely to offer custodial care for mentally handicapped patients but made financial provision for and encouraged research into the causes, treatment and prevention of mental handicap. He established the first research centre in the country under the leadership of Professor Berry who was appointed just before Mr Burden died on 15 May 1930. Professor Berry was an excellent leader and multi-disciplinarian and appointed a number of people from various spheres of medicine and formed good relationships with Bristol and London Universities.

Professor Berry, anatomist, Dr Norman, neuropathologist and Dr Gordon, neurologist and psychologist, soon became nationally and internationally renowned for their work. Incidentally Dr Gordon's son, the late Dr Ian Gordon, radiologist at the United Bristol Hospitals in Bristol, contributed greatly to research in mental handicap and was co-founder with Professor Butler in 1969 of the Bristol Registry of Bone Dysplasias.

In 1933, Mrs Burden donated the sum of $£ 10,000$ and with the gift expressed her desire that it should primarily 
be devoted to problems underlying the causation and inheritance of normal and abnormal mentality. The Burden Mental Research Trust came into being.

Dr Fraser-Roberts was one of the leading minds at that time and he became world renowned for his genetic approach, psychological approach and other studies of mental handicap. He was the first doctor in the field of mental handicap to receive the Fellowship of the Royal Society.

Dr R. Griffiths, psychologist, made a great impact in psychological research (Griffiths Scale-Psychological Test). Numerous publications and discoveries were made at that time particularly when full-time biochemist, $\mathrm{Mr} \mathrm{A}$. $\mathrm{H}$. Tingey became a member of the research team. In 1939 Mrs Burden gave further financial support to the Burden Neurological Institute which opened on 12 May 1939 when Professor F. L. Golla was appointed director of the Institute and Dr Grey Walter was in charge of the physiological research unit. They, with their teams, greatly contributed to the care and treatment of mentally handicapped people especially in relation to the treatment of epilepsy.

In 1948, Stoke Park Colony was absorbed into the National Health Service. Soon after Dr Norman became the Director of Neuropathology at Frenchay Hospital and the rest of the research team was unfortunately disbanded and members moved to London and Oxford. However, in 1954, Dr Heaton-Ward, the new Medical Superintendent, rekindled the spirits of his predecessors.

The links with the University and other local and national hospitals were gradually re-established and support was given by such eminent people as Professor Penrose, Professor Dent and locally Dr Eastham, who contributed greatly in the field of biochemistry, and Dr F. Lewis and recently Dr A. McDermott in the field of chromosomal studies. Apart from research, the links with the community were first established in 1958 in the Central Health Clinic where, in conjunction with Bristol Local Health Authority, the first assessment clinics were held by Dr A. HeatonWard, Dr Lumsden-Walker and Dr J. Jancar and others followed at the Gloucester Royal Hospital, Bush Training Centre, Yate and Kingswood Health Centres. ${ }^{3}$

In October 1961, at Hanham Hall Hospital, a new assessment unit was opened and 10 years later a multi-disciplinary assessment unit was built at Stoke Park Hospital. ${ }^{4}$

In 1969, the Burden Trust instituted an annual award'The Burden Research Medal and Prize' for outstanding research work in the United Kingdom and Ireland to encourage future research in the field of mental handicap. Nine people have now received this coveted award.

In 1982 the post of Senior Lecturer in Mental Handicap at the Bristol University jointly with Stoke Park was established and, at the same time, a Lecturer's post. The first holder of the lectureship was the late Dr Graham Carter who tragically died.

It is interesting to note that, since research began at Stoke Park Hospital, 17 books, six chapters and over 350 papers have been published.

Hortham Colony was the first institution to be designed and built as a complete colony and was opened on 29 April 1932. It was built by Bristol City Council and the first patients were admitted from existing poor law establishments at Stapleton and Southmead. The first Medical Superintendent was Dr Walter Wyatt who came from Darenth Training Colony but who later left for Australia. His successor as Medical Superintendent was then Assistant Medical Officer, Dr J. F. Lyons who showed by his outlook and leadership, an extraordinary ability to mould patients and staff into what he described as "our family at Hortham". In 1948 Hortham Colony joined with Brentry Hospital and became part of the National Health Service.

In 1955 Dr Lyons retired and Dr W. Lumsden Walker succeeded him as Medical Superintendent. He continued with the philosophies of Dr Lyons and added new ideas. He continued to forge links with the community and left in 1968 to take up a post at the Bristol Children's Hospital and child guidance. The gap was successfully filled by Dr Gordon-Russell who maintained and increased the momentum of progress until his recent retirement. The staff at Hortham and Brentry also produced interesting publications. $^{5}$

The Social Services have also played an important role in the provision of services for the mentally handicapped in Bristol, Bath and Somerset. In the late part of the last century, various committees were looking at the variety of facilities and provisions to ameliorate their hardships and, before and after the passing of the 1913 Mental Deficiency Act, a number of centres were opened.

In 1916 the Bristol Board of Guardians consented to the certification of the Stapleton Workhouse for the reception of 50 mentally handicapped patients. Somerset County Council had taken over Yatton Hall in October 1919. In January 1920 temporary accommodation for the juvenile mentally handicapped was opened at Southmead Hospital. Marlborough House was opened by the Bristol Corporation in 1942. In 1963 the Bush Training Centre was opened and in 1965 Blackhorse Training Centre and Lanercost Road in 1977. During the past two decades a number of residential hostels in Bristol and Bath were also provided.

Another important contribution to the care of mentally handicapped people in Bristol was made by voluntary organisations. St Christopher's Private School was opened in 1942 by Miss Grace who was trained at Stoke Park Hospital. Manor House, Frenchay, received the first mentally handicapped children in 1950. The Sheiling Curative School opened in Thornbury in 1952 and recently Priory Court in Hanham and Berwick Lodge, purchased from Southmead Health Authority.

The Bristol Industrial Therapy Organisation opened in 1960 , under the guidance of Dr Early, where a number of mentally handicapped, until quite recently, were helped and employed.

A number of Bristol, Bath and Somerset counsellors were active in the care and provision for mentally handicapped people and some outstanding social workers, e.g. Morton, Penington and others, contributed greatly towards the welfare of the patients and their families. The League of 
Friends, Mencap, Parents' Association, the Community Health Council and others also played an important part in providing a better care and future for the mentally handicapped in Bristol and Bath.

\section{REFERENCES}

'Shuttleworth, G. E. \& Potts, W. A. (1910) Mentally Deficient Children: Their Treatment and Training, third edition. London: H. K. Lewis.
${ }^{2}$ JANCAR, J. (1972) Fifty years of Brentry Hospital (1922-1972). Bristol Medico-chirurgical Journal, 87, 23.

3 __ (1981) Research at Stoke Park, Mental Handicap (1930-1980) The Supplement to Stoke Park Studies. Dorchester: Henry Ling, Dorset Press.

_ (1971) Assessment unit for the mentally retarded. (A further observation). Bristol Medico-chirurgical Journal, 86, 27.

${ }^{5}$ UpHAM, B. C. \& ROBERT, P. J. (1982) Hortham Hospital. Golden Jubilee-History of Change.

\title{
Conference Report
}

\section{Preventing Alcohol Misuse}

\author{
E. B. Ritson, Consultant Psychiatrist, Royal Edinburgh Hospital, The Andrew Duncan Clinic, Edinburgh
}

This Conference, organised by the Department of Health and Social Security, was held at the King's Fund Centre on 20 February 1987. It was chaired by Professor Griffith Edwards and was attended by representatives of health, social work, education, the media, the alcohol industry, voluntary agencies and a number of other relevant interest groups. The keynote speech from the Rt Hon Norman Fowler set the scene for the day's discussions. He emphasised the importance of bringing about a change in public attitude towards alcohol. He made a number of positive and encouraging references to the College's Report and endorsed some of its recommendations. He acknowledged the influence of price and availability on levels of consumption and the part which Government can play in influencing these factors. He also recognised that a wide range of government departments were involved in various aspects of alcohol problems, mentioning particularly the Home Secretary's Standing Conference on Crime Prevention; working groups on young people and alcohol, and juvenile crime; and the Department of Transport's concern with drinking and driving. He also expressed concern about the images presented by the media.

In recognising the all-pervasive influence of injudicious drinking, he pointed out the importance of generating an effective community response and the need to make the most effective use of existing resources.

Professor Anthony Clare reviewed alternative prevention strategies, dispelling the myth of two drinking populations and underlining the fact that per capita consumption was a crucial factor governing the overall level of harm in the population. He also emphasised the particularly damaging consequences of intoxication for the 15-24 year old group. He asked "How can we make intoxication socially unacceptable?". He also pointed out that the funds devoted to health education are miniscule compared with those which the drink trade devotes to advertising. Advertisements promoting alcohol are very carefully conceived and based on an intimate knowledge of the consumer group to which they are addressed. Lack of funds prevents a similar level of detail, knowledge and skill being made available to the promotion of sensible drinking and information about the health risks involved.

Professor David Robinson from the University of Hull outlined the ways and means and tactics for prevention initiatives. He emphasised the kinds of projects which could be undertaken by interested groups at a local level.

There were six discussion groups concerned with alcohol and young people, alcohol in the workplace, alcohol and the media (excluding sports promotion and TV advertising), marketing, retailing and advertising of alcohol (including sports promotion and TV advertising), barriers to intervention, and a co-ordinated approach to local action. These groups then reported with brief statements of future preventive initiatives. Baroness Trumpington concluded the meeting with the promise that a report on the day's proceedings would be made available to participants.

\section{Comment}

The Government position reflected a refreshing willingness to acknowledge the range of alcohol-related problems and their responsibility for a commitment to prevention. I was encouraged by the extent to which the recommendations of the College's own report were echoed in the Minister's speech. 